可視化情報 Vol. 10 Suppl. No. 2 (1990年11月)

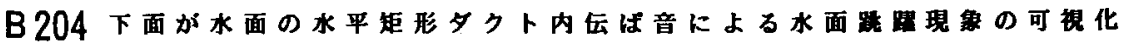

埼玉大学部川檑正昭。

埼玉大工学部細井健司

埼玉大院荒川雅裕

VISUALIZATION OF RUPTURES OF A LIQUID SURFACE

By STRONG SOUND WAVE PROPAGating IN A PARTIALly LIQUID-FILLED DUCT

Masaaki KAWAHASH ${ }^{*}$, Kenji HOSOI* and Masahiro ARAKAWA**

When a strong sound wave is attenuated by friction in a unsteady boundary layer adjacent to a solid wall, an acoustic streaming is produced. The acoustic streaming is a steady motion defined by the steady part of second-order velocity caused by non-linearity in a wave motion. A creeping motion generated by a standing wave formed in a pipe by intense sound is known as a typical acoustic streaming which forms dust patterns in a Kundt's tube. And also a second-order pressure distribution is generated in a standing wave. The pressure distribution is shown by deformation of a surface of liquid that partially fills a tube. And when the sound pressure exceeds a certain threshold value, a rupture of liquid surface is occur and fountains are present at sound pressure nodes. This report presents visualization of the fountains and critical values of sound pressure for ruptures of liquid surface.

1 。まえがき

一端を閶じた管内の伝ぱ音によって生じる定常波の節または腹の間隔を可梘化して計测 し、その伝战音の周波数を調べる方法は、クント篔法と呼ばれ、典型的な物理実䮩の一つ として広く行われている。その可視化法は、水平管内にコルク䉽またはリポコジウムなど を散布し、それらが定常波の音圧の節または腹部に移動して生じる縞模粎を観察するもの である。この微粉末が移動する現象については、古くから多くの研究者の関心を集め、そ の基本的メカニスムについての定性的説明かなされてきたいいいる。それらは以下のようて ある。伝ぱ音の音圧レベルの增加とともに波動の非線形効果が現れ始め、二次の項の定常

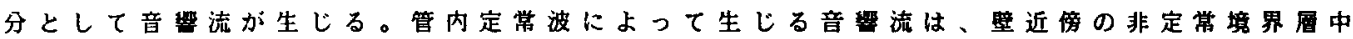
で節部に向かう流れとなって現れ、その流れが節部と腹部、および对称軸に囲まれた領域 に循環流を形成し、この诸罢流が澈粉末の移動をもたらすと説明されている。しかし、実 際に覞察される現象は単純ではなく、粷末の粒径、此重などによって編の現れ方が变化し たり、粉が膜状に舞い上がる現象等も報告されている(3)。このような現象については、 二次的な流れの発生たけては十分に説明されず、その発生要因はいまたに明らかにされて いない。

さらに、このような高音圧状贸の定常波では二次の圧力頁が生じて、その定常分は管軸

* Dept, of Mech. Eng., Saitama Univ,,255 Shimo-okubo,Urawa,Saitama 338

** Saitama Univ., Graduate Student 
方向に平均压力の变化をもた らす。その結果、定常波の音 圧の節部は低圧部、腹部は高 圧部となる。この平均压力分 布は、下部を液体て満たした Axis of symmetry

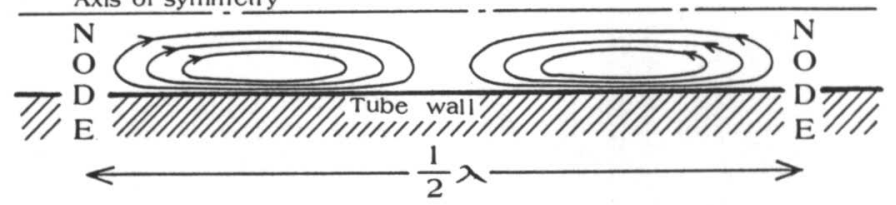

管内の定常波による液面の変

Fig. 1 Illustrating streening generated by standing wave. 形から可視化される4!。さ らに、音圧の值があるレペル を越えると、突然压力極小点! において噴水状に液面が吹き 上かる。このような現象は、

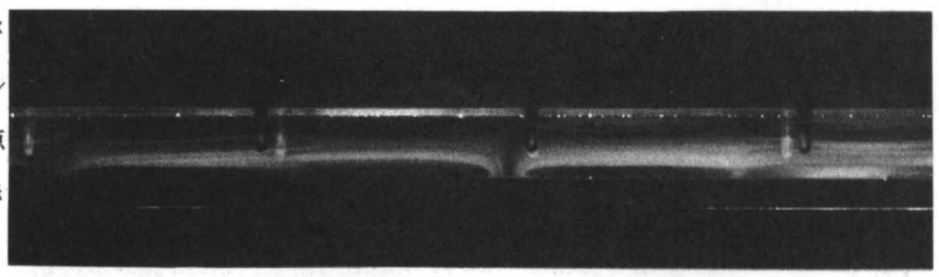
中国に古くから伝わる”魚のFig.2 Visualization of acoustic streening generated in duct. 泉”と呼ばれる水鉢で起こる嘖水現象を想起させる‘ 5 。

本報告では、高出力音源によって駆動される一端を閉じた矩形断面タタト内気柱振動の 定常波によって生じる噴水現象を可視化するとともに、タタト内音圧および变動波形の計 測を行ないその結果を示す。

\section{2 。実験結果および考察}

Lord Rayleighは、平行平板間の平面波伝ぱ音による定常波によって、二次の才ーター の項として音響流か現れることを示し、その音響流がFig. 1 に示すような対称の循環流 を形成することを示した。このような音暗流については、煙を注入した円管内の可視化に よって、軸対称循環流の存在が確珰されている。そこて本報告では、はじめに矩形タクト 内の定常波に伴う音製流の存在を、レーザライトシート法による可視化で確䏰する。供試 タクトの断面形状は、 $25 \mathrm{~mm} \times 60 \mathrm{~m} \mathrm{~m}$ の矩形であり、長さは $1,500 \mathrm{~m} \mathrm{~m}$ であ。タクトには線香 の煙が注入され、スピーカー音源からの音の供給により定常波が生じる。このときタクト 長さ方向の左右対称面が、レーザピームスキャニング法によるシート光で照明され、照明 面の散乱光パターンが写真撮影される。撮影された写真例が Fig. 2 に示されている。こ のときの音源周波数は958Hzてある。得られた結果は、循環流バターンを示しており、音 流の存在か確涊される。しかし、この㑑環流の構造は通常上下対称でなく、照明面を ずらすと異なったパターンが 観 察される。

つきに、本報告の本来の目的 である噴水現象の可視化に用い た実験装置概略図か、Fig. 3 : 示されている。用いたタクトは アクリル製であり、その長さは $600 \mathrm{~mm}$ 、幅は $60 \mathrm{~mm}$ 、深さは $75 \mathrm{~m} \mathrm{~m}$

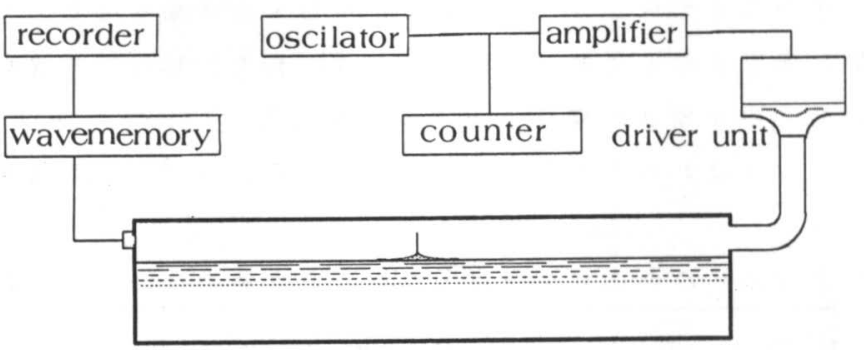

Fig. 3 Schematic view of experinental apparatus. 


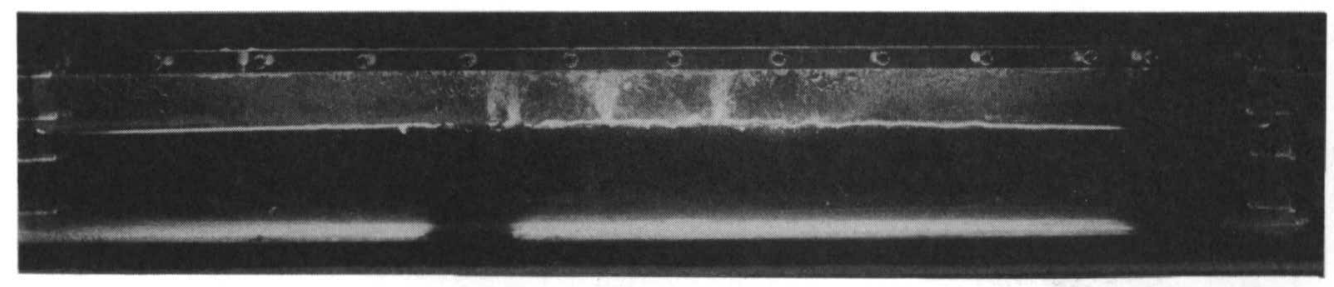

(a) 1 st mode of standing wave $(279 \mathrm{~Hz})$.

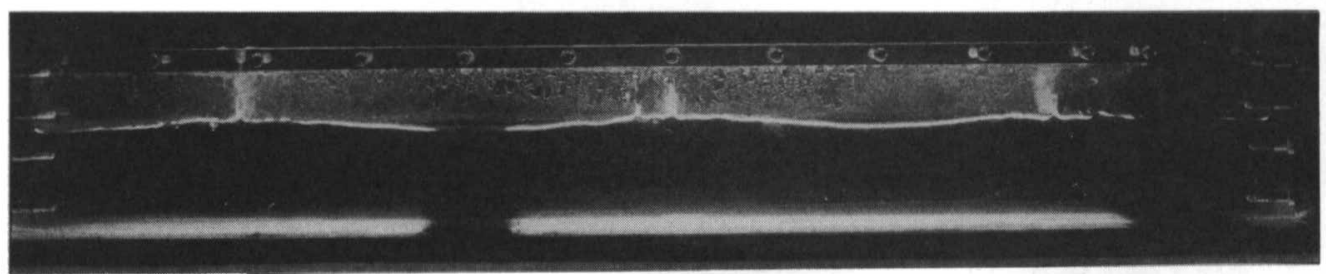

(b) 3rd aode of standing wave $(830 \mathrm{~Hz})$.

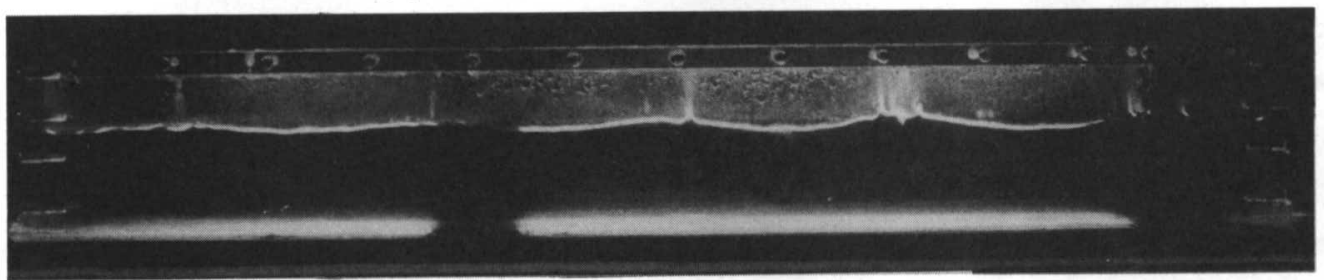

(c) 5 th wode of standing wave $(1390 \mathrm{~Hz})$.

Fig.4 Visualization of deforations of water surface generated by standing wave in duct.

\begin{abstract}
である。このタクト下部を水で满たし て水深を $50 \mathrm{~mm}$ とし、上部の空間部高さ を2 $5 \mathrm{~mm} に$ に保つ。また、水面吹き上げ現 象が生じているとき水中に誘起される 流れを可視化するため、粒徍約 $10 \mu \mathrm{m}$ のナイロン粒子が混入されている。タ クトのー端には音源であるホーンスピ 一カー用ドライバーユニットが設置さ
\end{abstract} れ、他端にはタクト内音圧測定用の半

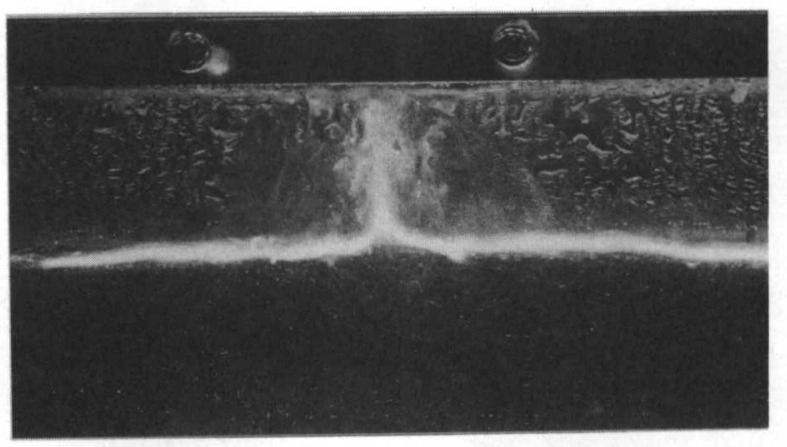

Fig. 5 Visualization of "fountain".

導体圧力变換器が取付けられている。実験では、音源のドライバーュニットは100 Wの増 幅器で駆動され、その周波数はタクト長さがちょうど1/2 波長の整数倍になるように調整 される。このとき、音圧の增加とともにタクト内水面は $1 / 2$ 波長ごとに一つの山が形成さ れるように変形する。さらに音压が增加してある值を越えると、突然水面形状の凸部頂点 から噴水状に水が吹き上がる。

この噴水現象の可視化写真が、定常波の 1 次、3 次および 5 次の各モードについて Fig. 4 に、また嗔水部拡大写真かFig.5に示されている。各モードにおける嗔水現象は、定 常波の音圧の各節部において一個所または複数個所で生じる。とくに一次のモードでは、 常に複数の吹き上がりが钼察される。この噴水現象は、タクトの上壁に到達し、上壁に強 


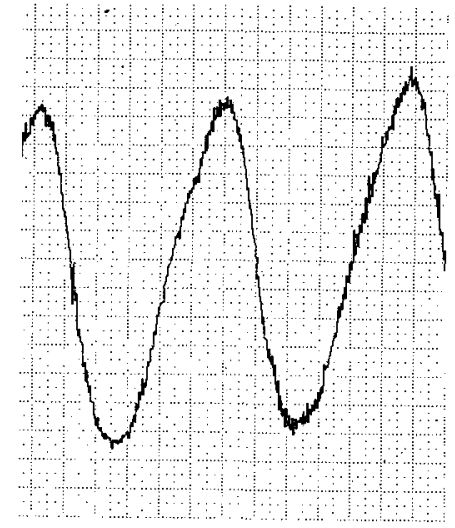

(a) Ist code $(279 H z)$.

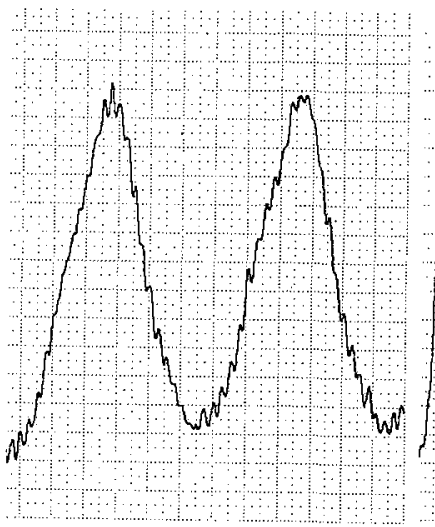

(b) 3rd wode $(830 \mathrm{~Hz})$.

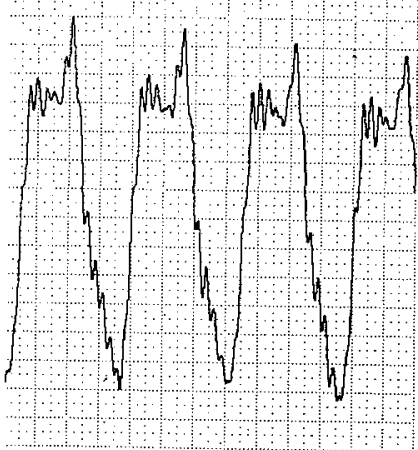

(c) 5 th oode $(1390 \mathrm{~Hz})$.

Fig. 6 Critical pressure waves at closed end of duct.

く打ち当たる势いを示す。㯰水部を搪大して観測した結果から、水の吹き上げは同所的に 発生していること、啨水部近くの水の表面に波長の短いさざなみが生じていること、水中 に唀起される流れは水面の柾く近㒀に限らることなどが観察された。

つきに、嗔水現象が発生する直前のダクト閉端部圧力波形が、Fig.6に示されている。 測定された開端压力波形はいずれも高調波成分を含み歪んでいるが、做水発生の臨界閉端

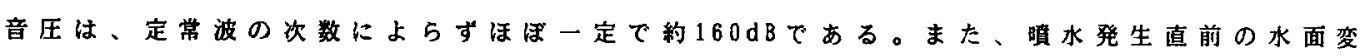
形による水位差は、山部と谷部で約10日四であり、タクト内に的 $0.1 \mathrm{kPa}$ ほ 差が生じることがわかる。嗔水現象の発生とともに水面は不安定になり、重力波伝ぱによ る定常波状態で周期的に振動しはじめる。その水面の振動の周期で、タクト内定常波振幅 も变動し不安定になる。

3。あとがき

强い音埸下で生じる二次流の発生、および二次のオーターの圧力分布について、矩形断 面タクト内に定常波を発生させることにより䚁祭した。その結果、とくに下部を水で㴖た したタクト内の水面か、嘈水状に吹き上がる現象を確櫂することが出来たが、その発生要 因を明らかにする手がかり得るまでには至らなかった。今後、水面の变形と同时に気柱 部二次流の可視化を行ない、その閉連性を調べる必要があるものと思われる。釉わりに、 本実驗に協力された、本学学生上田敦君に韵意を表する。

\section{文献}

(1)Lord, Rayleigh, "Theory of Sound \#", Dover Pub.Inc., New York(1945), 333 .

(2)Andrade, E.N.Da C, Phil.Trans.Roy.Soc.,A230(1932),413.

（3）安達, 他 2名、Nagare,11-4(1980),25.

(4)Ingard,U \& Galehouse,D.C., AJP, 39(1971),811.

(5)日本音等会誌, 28-6(1972),317. 